\title{
Magdalena Kempna-Pieniążek
}

ORCID: 0000-0002-2569-5596

Uniwersytet Śląski

\section{Niedokończona konkwista. O niezrealizowanym projekcie filmowym Wernera Herzoga}

\begin{abstract}
Abstrakt: Artykuł ukazuje niezrealizowany projekt Wernera Herzoga pt. The Conquest of Mexico na tle skomplikowanej relacji łączącej reżysera z kinem głównego nurtu. Film, który miał zainicjować bliższą współpracę niemieckiego twórcy z Francisem Fordem Coppolą, z biegiem czasu osiągnął status jednego z ,nieukończonych arcydzieł”. Próbując odpowiedzieć na pytanie o przyczyny porażki przedsięwzięcia, autorka poddaje refleksji status europejskiego twórcy we współczesnym Hollywood. Istotnym kontekstem podjętych w artykule wątków jest powstanie Indiewood — sfery, w której wpływy kina mainstreamowego spotykają się z potencjałem kina niezależnego, a twórcy, tacy jak Werner Herzog, mogą odnaleźć swoje miejsce bez konieczności rezygnacji ze swojej artystycznej wizji.
\end{abstract}

Słowa-klucze: The Conquest of Mexico, Werner Herzog w Ameryce, Indiewood

Kiedy uczestnicy wyprawy zaczynają powątpiewać w możliwość sukcesu i domyślają się, że ich przywódca ściga nie Eldorado, lecz jego iluzję, Lope de Aguirre stwierdza: „Meksyk nie był iluzją”. Paradoksalnie, dla Wernera Herzoga, twórcy filmu Aguirre, gniew Boży (Aguirre, der Zorn Gottes, 1972), w którym pada to znamienne zdanie, to właśnie konkwista Meksyku na swój sposób okazała się niezrealizowanym snem.

Niewiele wiadomo o tym projekcie, który zresztą wypadałoby uznać nie za nieukończony, lecz wręcz za nierozpoczęty. W dostępnych źródłach — swoją drogą, bardzo skąpych — odnaleźć można zaledwie garść informacji na temat tego, że Werner Herzog planował realizację filmu The Conquest of Mexico. Chociaż jednak przedsięwzięcie nie wyszło poza etap konceptualny i - poza ogólnym zarysem pomysłu — prawie nic nie wiadomo o jego scenariuszu, film jest konsekwentnie umieszczany przez internautów w rankingach nieukończonych arcydzieł czy niezrealizowanych klasyków ${ }^{1}$, obok Jądra ciemności Orsona Wellesa

1 Zob. na przykład http://www.cinelinx.com/editorial/item/3282-classics-that-might-have-been25-unmade-films-part-1.html (dostęp: 20 sierpnia 2018); http://www.tasteofcinema.com/2014/the-

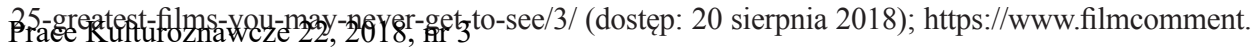
(C) for this edition by CNS 
czy Napoleona Stanleya Kubricka. Szczególny kredyt zaufania, jakim niedoszli widzowie obdarzyli pomysł Herzoga, wydaje się podszyty przekonaniem, że twórca, który w niestandardowy sposób opowiedział historię Lopego de Aguirre, z pewnością i do tematu konkwisty dokonanej przez Hernána Cortésa podszedłby w odkrywczy sposób. W tym kontekście trafne wydaje się przyjęcie perspektywy, o której wspomina Marcin Adamczak w swojej propozycji traktowania filmów nie jako obiektów, ale dziejących się wciąż procesów „o różnym stopniu intensywności i wyrazistości, także o pewnym niebagatelnym życiu prenatalnym"2. Jak dowodzi badacz, w takiej optyce ,istnienie bądź nieistnienie [filmu — przyp. M.K.P.] nie jest przez nas postrzegane jako prosta relacja binarna, lecz jako rzecz stopniowalna”, a wybrane projekty „mogą istnieć jako pewne społeczne oczekiwanie, niezależnie czy autentyczne, czy trochę kreowane"3. Opis ten wydaje się adekwatny między innymi dla The Conquest of Mexico — dzieła, które, choć nie istnieje materialnie, funkcjonuje w świadomości znawców i wielbicieli twórczości Herzoga, o czym świadczą wspomniane rankingi niedokończonych arcydzieł.

W recepcji wiadomości dotyczących potencjalnej realizacji The Conquest of Mexico bardzo istotne miejsce zajmuje wątek relacji tego projektu z kinem hollywoodzkim. Czy film ten mógł się okazać akcesem niemieckiego twórcy do mainstreamu? Czy źródeł niepowodzenia przedsięwzięcia należy upatrywać w autorskiej strategii reżysera, odległej od systemu pracy wielkich wytwórni filmowych? A jeśli tak, to czy porażka The Conquest of Mexico, paradoksalnie, nie powinna być uznana za sukces Herzoga w walce o zachowanie artystycznej niezależności? Pytania te przewijają się w nielicznych dostępnych artykułach na temat tego projektu, a DisRegarding Henry, twórca internetowego serialu Unmade Masterpieces, niemal w całości poświęca im odcinek o The Conquest of Mexico. Z braku dostatecznej ilości danych, przede wszystkim zaś dlatego, że projekt nie wszedł na etap realizacji, który pozwoliłby na dokonanie jego rzeczowej analizy, zamierzam podążyć wspomnianym tropem.

W obecnej chwili nie jest dostępna żadna wersja scenariusza tego dzieła, w związku z czym - nawiązując do klasyfikacji Camilli Bevilacqua przytoczonej przez Łucję Demby - nie sposób mówić o The Conquest of Mexico ani jako o filmie konkretnym, materialnie istniejącym, ani jako o filmie wyobrażonym, nazywanym przez autorki nieco paradoksalnie „filmem prawdziwym, tym, który zrodził się z natchnienia i tęsknoty artysty"4. Wiadomo jedynie, że planowana

com/article/unproduced-and-unfinished-films-a-ongoing-film-comment-project/ (dostęp: 20 sierpnia 2018); http:/thisisinsider.com/the-best-movies-never-made-2016-9\#the-conquest-of-mexico-by-werner-herzog-5 (dostęp: 20 sierpnia 2018).

2 Zob. M. Adamczak, Jak istnieje film? O ruchomych obiektach i teorii Aktora-Sieci Bruno Latoura, [w:] Kino, którego nie ma, red. P. Zwierzchowski, D. Wierski, Bydgoszcz 2013, s. 14.

3 Ibidem.

4 Ł. Demby, O wrażeniu nieistnienia kina. Koncepcja kina mentalnego na przyktadzie wybranych wątków z teorii kina, [w:] Kino, którego nie ma..., s. 38. 
przez Herzoga realizacja miała być opowieścią o hiszpańskiej konkwiście zaprezentowaną z perspektywy Azteków, co jeszcze kilka dekad temu, przed powstaniem filmów takich jak Podróż do Nowej Ziemi Terrence'a Malicka (The New World, 2005) czy Apocalypto Mela Gibsona (2006), musiało się wydawać pomysłem jeśli nie najbardziej oryginalnym, to przynajmniej dość śmiałym.

Nie jest pewne, kiedy dokładnie Herzog zaczął myśleć o realizacji tego projektu. Być może - jak chcą niektórzy krytycy - stało się to już w czasie bliskim powstania Aguirre, gniewu Bożego ${ }^{5}$, może nawet jeszcze wcześniej, w latach sześćdziesiątych, gdy reżyser zainteresował się Meksykiem w wyniku — jak sam twierdzi — dość awanturniczej przygody, kiedy to, porzuciwszy studia na Uniwersytecie w Pittsburghu, po tygodniach koczowania zimą w zardzewiałym samochodzie w towarzystwie milczących bezdomnych, musiał uciekać ze Stanów Zjednoczonych w obawie przed ekstradycją ${ }^{6}$. Doświadczenia z ówczesnej wyprawy do Meksyku zaowocowały fascynacją kulturą latynoamerykańską. O trwałości tego wątku świadczą ciągle powracające echem w dorobku reżysera tematy kolonizacji Ameryki czy jej specyficznej duchowości (warto zwrócić w tym kontekście uwagę choćby na średniometrażowy film dokumentalny Christ and Demons in New Spain, 2000). Co ciekawe, wśród książek, które Herzog od lat poleca w wywiadach swoim widzom, niezmiennie widnieje tytuł Prawdziwa historia podboju Nowej Hiszpanii Bernala Díaza del Castillo ${ }^{7}$ — jedno z najważniejszych źródeł o konkwiście Meksyku dokonanej przez Cortésa, które reżyser uczynił nawet obowiązkową lekturą dla swoich studentów w ramach okazjonalnie prowadzonych kursów filmowych ${ }^{8}$.

Prawdopodobne wydaje się, że pomysł nakręcenia The Conquest of Mexico dojrzał na przełomie lat siedemdziesiątych i osiemdziesiątych XX wieku, kiedy reżyser był już postrzegany jako ikona europejskiego kina autorskiego i kiedy nawiązał z Francisem Fordem Coppolą kontakt, który mógł zaowocować realizacją wspólnego przedsięwzięcia. Późniejsze informacje na temat filmu są ściśle związane z producencką działalnością Coppoli, co sugeruje, że miał to być projekt, którym Herzog podjąłby bliższą współpracę z Hollywood. Większość prasowych informacji powtarza przypisywaną reżyserowi opinię, której oryginalnego źródła nie udało się jak dotąd ustalić, że to sam Herzog zabiegał o wsparcie wielkich wytwórni, kiedy uświadomił sobie, iż jego pomysł wymaga znacznie większych nakładów finansowych niż te, którymi do tej pory dysponował. Na podstawie dostępnych materiałów można się domyślać, że to właśnie wzloty i upadki Ame-

5 Zob. Unmade masterpieces: Werner Herzog's The Conquest of Mexico, https://www.youtube. com/watch?v=u5SnJ9tKeWE (dostęp: 30 sierpnia 2018).

6 Zob. P. Cronin, Herzog on Herzog, London-New York 2002, s. 20-21.

7 Zob. E. McCarthy, 14 things we learned from Werner Herzog's Reddit AMA, http://mentalfloss. com/article/83030/14-things-we-learned-werner-herzogs-reddit-ama (dostęp: 30 sierpnia 2018).

8 Zob. http://www.faena.com/aleph/articles/the-films-and-books-werner-herzogs-students-mustwatch-and-read/ (dostęp: 30 sierpnia 2018). 
rican Zoetrope, studia założonego w 1969 roku przez Francisa Forda Coppolę i George'a Lucasa, decydowały o opóźnieniach w realizacji oraz o następujących co jakiś czas powrotach do koncepcji niemieckiego reżysera. Wiadomo, że pierwotnie twórca Czasu apokalipsy (Apocalypse Now, 1979) zamierzał przeznaczyć na realizację filmu Herzoga dwadzieścia milionów dolarów, jednak finansowe fiasko wyprodukowanego przez American Zoetrope Tego od serca (One from the Heart, 1982) Coppoli przekreśliło te plany 9 .

Mimo iż przez część krytyków pomysł uznawany był za przykład klasycznej finansowej pułapki - kosztowny film realizowany przez reżysera spoza kina głównego nurtu - Coppola jeszcze w drugiej połowie lat dziewięćdziesiątych zarzekał się, że artystyczny potencjał projektu wart jest ryzyka i dodawał, że Werner Herzog i Klaus Kinski potrafili znikać w dżungli na całe miesiące, ale ostatecznie zawsze wracali z niej z gotowym filmem ${ }^{10}$. Wypowiedź ta pochodzi z czasu, kiedy Herzog i Coppola znaleźli się najbliżej urzeczywistnienia swojego zamysłu. Wówczas to pojawiły się w mediach sugestie co do obsady głównych ról w The Conquest of Mexico: twierdzono, że Cortésa zagra Ralph Fiennes, a Montezumę Jimmy Smits.

Między 1996 a 1997 rokiem powstały najprawdopodobniej dwie wersje scenariusza: pierwsza, autorstwa samego Herzoga, najwyraźniej okazała się niesatysfakcjonująca dla hollywoodzkich producentów, ponieważ do jej przerobienia zatrudniono Johna Miliusa, znanego jako reżyser Conana Barbarzyńcy (Conan the Barbarian, 1982), a także współscenarzysta takich projektów, jak Brudny Harry (Dirty Harry, 1971) Dona Siegela oraz — i być może to okazało się decydujące Geronimo: amerykańska legenda (Geronimo: An American Legend, 1993) Waltera Hilla. Mając na uwadze charakter fabuł konstruowanych przez Herzoga w filmach takich, jak Aguirre, gniew Boży czy Fitzcarraldo, nietrudno domyślić się, co z perspektywy amerykańskiego mainstreamu mogło w jego scenariuszu wymagać korekty i jak owa korekta mogła wyglądać, jeśli zlecono ją twórcy filmowego Conana. Koniec końców, projekt spalił na panewce: druga wersja scenariusza nie usatysfakcjonowała Herzoga, który oprotestował pomysł jednowymiarowej charakterystyki hiszpańskich konkwistadorów jako ludzi opętanych żądzą azteckiego złota $^{11}$. Do porozumienia nie doszło, przedsięwzięcie nie zostało zrealizowane, a projekt, który jeszcze w 1997 roku odnotowywany był przez krytyków ${ }^{12}$ jako

9 Zob. M. Sragow, Francis Ford Coppola, http://www.salon.com/1999/10/19/coppola/ (dostęp: 30 sierpnia 2018).

10 Zob. D. Chute, Coppola's rainbow, http://articles.latimes.com/1998/aug/14/entertainment/ca12942/2 (dostęp: 20 sierpnia 2018).

11 Zob. C. Zigman, Werner Herzog's Hollywood, http://www.hollywoodfiveo.com/archive/issue2/ cinema/herzog.htm (dostęp: 30 sierpnia 2018).

12 Jako taki odnotowuje go między innymi Geoffrey O'Brien, który w 1997 roku spotkał się i rozmawiał z Herzogiem Geoffrey O'Brien with Werner Herzog, http://parnassusreview.com/archives/388 (dostęp: 30 sierpnia 2018). 
pozostający na etapie realizacji, na przełomie wieków zniknął z oficjalnego obiegu. Obecnie szanse na powrót do niego wydają się nikłe, zważywszy na bardzo chłodną recepcję i spektakularną finansową porażkę Królowej pustyni (Queen of the Desert, 2015), filmu, w którym Herzog najbardziej w swojej karierze zbliżył się do konwencji hollywoodzkiego widowiska z gwiazdorską obsadą.

Warto w tym miejscu zwrócić uwagę na przynajmniej dwa mity, którymi są podszyte dostępne w mediach narracje na temat The Conquest of Mexico. Jeden z nich dotyczy tego, że film o Aztekach był pierwszą próbą nawiązania współpracy między Herzogiem i Hollywood; drugi związany jest z przyczynami porażki projektu: pomijając kwestie wzlotów i upadków American Zoetrope, jako powód niezrealizowania przedsięwzięcia na ogół wskazuje się charakter reżysera, niepotrafiącego pracować $\mathrm{w}$ restrykcyjnych warunkach kina rozumianego jako przemysł. Z medialnych doniesień wyłania się portret Herzoga jako reżysera, który - mimo iż, jak nieco niezgrabnie ujął to jeden z krytyków, stanowi najlepszy niemiecki nabytek amerykańskiego kina od czasów Fritza Langa ${ }^{13}$ — nieustannie tkwi w świecie wyższych idei i, niepomny czysto pragmatycznego wymiaru sztuki filmowej, gotów byłby zaprzepaścić ogromny budżet w celu realizacji swoich najbardziej fantastycznych i — co gorsza - zupełnie niekomercyjnych wizji. Wniosek, jaki płynie z tych rozpoznań, wydaje się oczywisty: jeżeli Herzog będzie realizował filmy w Ameryce, to jedynie w obszarze kina niezależnego.

Być może na recepcji związków Herzoga z Hollywood przez amerykańską krytykę zaważyła wizja Stanów Zjednoczonych zawarta w Stroszku (1977) — filmie, który bywa czasem postrzegany jako krytyczny głos reżysera w sprawie amerykańskiego snu ${ }^{14}$. Jak słusznie zauważa Marcin Giżycki, „dyskusja, jaką film wywołał, poszła w zaskakującą stronę, omijając jego główne [...] przesłanie"15, a jej efekt okazał się jednowymiarowy: Herzog zaczął być postrzegany jako jeden $\mathrm{z}$ europejskich twórców, którzy — podobnie jak Michelangelo Antonioni w $\mathrm{Za}$ briskie Point (1970) czy Wim Wenders w Alicji w miastach (Alice in den Städten, 1973) - mają wysoce krytyczny stosunek do Ameryki i prezentują ją na ekranie jako „krainę bezdusznych uśmiechów”16. Andrew Sarris stwierdził wręcz, że podczas oglądania Stroszka ,czasami wydaje się, jakby Herman Hesse z Franzem Kafką połączyli siły, by zrobić buddyjską powtórkę Easy Ridera" ${ }^{17}$.

Tymczasem rzeczywisty stosunek Herzoga do amerykańskiej kultury nie jest jednoznaczny, o czym świadczą zarówno jego liczne wypowiedzi, jak i filmy fabularne oraz dokumentalne, które reżyser od lat realizuje między innymi w Stanach Zjednoczonych. Szczególnie ciepło Herzog wypowiada się o środkowym

13 Zob. C. Zigman, op. cit.

14 O amerykańskiej recepcji Stroszka zob. M. Giżycki, Wenders do domu! Europejskie filmy o Ameryce i ich recepcja w Stanach Zjednoczonych, Gdańsk 2006, s. 146-148.

15 Ibidem, s. 146.

16 Cyt. za: ibidem.

17 Cyt. za: ibidem, s. 147. 
zachodzie Ameryki, gdzie realizował Stroszka; jak twierdzi, miejsca, które da się scharakteryzować jako „środek niczego", to „serce Ameryki” ${ }^{18}$. Amerykańska kultura jawi się w filmach reżysera jako bardzo złożona: warto wspomnieć w tym kontekście o takich realizacjach, jak Operacja Świt (Rescue Dawn, 2006), Zty porucznik (The Bad Lieutenant: Port of Call - New Orleans, 2009), Synu, synu, cóżeś ty uczynit? (My Son, My Son. What Have Ye Done?, 2009), Otchłań. Opowieść o życiu i śmierci (Into the Abyss, 2011) oraz Lo i stało się. Zaduma nad światem w sieci (Lo and Behold. Reveries of the Connected World, 2016), a nawet wcześniejszy od Stroszka krótkometrażowy dokument Ile drzewa naciątby świstak. Uwagi na temat nowego języka (How Much Wood Would a Woodchuck Chuck... - Beobachtungen zu einer neuen Sprache, 1973). Co więcej, od niemal dwudziestu lat, czyli od czasu ślubu z amerykańską fotograficzką rosyjskiego pochodzenia, Leną Pisetski, reżyser mieszka w Los Angeles, a jego stosunek do tego miasta znacząco odbiega od często przypisywanej europejskim twórcom niechęci względem baudrillardowsko rozumianych symulakrów. W udzielanych wywiadach Herzog podkreśla, iż jego zdaniem sztuczny blask Hollywood to tylko powierzchnia, pozór, który może łatwo zmylić. Wspomina, iż wspólnie z żoną podjęli decyzję, że zamieszkają w mieście o największej kulturowej istotności ${ }^{19}$. Co szczególne, w jego wypowiedziach na ten temat powraca meksykański wątek: pytany o to, co najbardziej lubi w Mieście Aniołów, obok „kolektywnych snów świata ujętych w kino" i tolerancji względem mniejszości, reżyser wskazuje na wpływ Meksykanów, który uznaje za bardzo ożywczy ${ }^{20}$.

Herzog nie demonizuje Hollywood. Warto pamiętać, że kontakty reżysera z kinem głównego nurtu nie rozpoczęły się od prób realizacji The Conquest of Mexico ani też — co równie istotne - na nich się nie skończyły. W wywiadzie rzece udzielonym Paulowi Croninowi reżyser wspomina, że jeszcze pod koniec lat siedemdziesiątych XX wieku 20th Century Fox było zainteresowane koprodukcją i dystrybucją Nosferatu - wampira (Nosferatu: Phantom der Nacht, 1979). Herzog nie rozwodzi się nad szczegółami tej sprawy; bardziej interesuje go anegdota związana z tą próbą podjęcia współpracy. Wspomina zatem, jak nie chcąc jechać do Hollywood, zaprosił przedstawicieli wytwórni do Monachium, po czym w mroźny zimowy poranek wpakował czwórkę gości do starego nieogrzewanego volkswagena i wywiózł wszystkich na bawarską prowincję. „Byli zdumieni, że w budżecie przewidziałem tylko 2 dolary na scenariusz - mówi. — Ale ja potrzebowałem przecież tylko 200 kartek papieru i ołówka"21. Już ta wypowiedź wskazuje na to, że Herzog nie przyjmuje perspektywy twórcy marginalizującego

18 Zob. P. Cronin, op. cit., s. 141.

19 Zob. B. Ebiri, Werner Herzog on death, Los Angeles and avoiding introspection, http://www. ifc.com/2010/09/werner-herzog-my-son (dostęp: 30 sierpnia 2018).

20 Zob. U. Gonzalez, Werner Herzog loves LA: It's 'the city with the most substance', http:// www.thewrap.com/werner-herzog-says-los-angeles-city-most-substance/ (dostęp: 30 sierpnia 2018).

21 Zob. P. Cronin, op. cit., s. 12. 
fakt, iż jego filmy trzeba jakoś sfinansować, choć z pewnością kwota dwóch dolarów przewidzianych jako koszt powstania scenariusza świadczy o tym, że dla autora Stroszka kino to raczej sposób na życie niż na zarabianie pieniędzy. Fakt ten potwierdzają inne wypowiedzi reżysera, choćby taka, dość dosadna:

To nie pieniądze przenoszą statki przez góry, lecz wiara. I to nie pieniędzmi robi się filmy, lecz dłońmi. Trzeba zebrać tylko jedną małą kupkę pieniędzy i sprawić, aby wydawała się duża. Istnieje niemieckie przysłowie: „Diabeł zawsze sra na największą stertę”. A więc uzbieraj małą stertę pieniędzy, a diabeł na nią nasra ${ }^{22}$.

Tym, co najbardziej drażni Herzoga w kinie głównego nurtu, jest jednak nie jego pragmatyczne i finansowe wychylenie, lecz sposób organizacji działań. Jako przykład reżyser podaje kwestię realizacji słynnej sekwencji Fitzcarraldo, w której statek parowy zostaje przeciągnięty przez szczyt góry. Jak wspomina twórca, wytwórnia 20th Century Fox, w tamtym czasie zainteresowana udziałem w produkcji filmu, chciała zrealizować ten fragment w studiu, z użyciem makiet okrętu i góry, co dla Herzoga było absolutnie nie do pomyślenia. Jeszcze w czasie trwania negocjacji z wytwórnią reżyser zainicjował zatem proces budowania statków, co było czasochłonnym przedsięwzięciem, ponieważ w Iquitos, w którym realizowano zdjęcia, nie ma stoczni ${ }^{23}$. „W Hollywood — twierdzi Herzog — za dużo jest rytuałów i hierarchii, a niezależność oznacza wolność od tego typu kwestii"24. Jednakże samą niezależność reżyser również rozumie w specyficzny sposób: raczej jako stan umysłu niż jako tryb realizacji filmów. „Kino niezależne nie istnieje, nie licząc filmów realizowanych na użytek rodzinnego archiwum"25 — stwierdza dobitnie. Taka postawa z pewnością ułatwiła reżyserowi w późniejszych latach podjęcie ograniczonej współpracy z przedstawicielami Hollywood: warto wspomnieć w tym kontekście, że jednym z producentów Synu, synu, cóżeś ty uczynit? był David Lynch, a wytwórnia MGM podjęła się dystrybucji Operacji Świt.

Pozostaje jeszcze, rzecz jasna, kwestia konwencji hollywoodzkiego widowiska, które Herzog potraktował z całkowitą obojętnością w filmach, takich jak Zly porucznik, Synu, synu, cóżeś ty uczynit? czy Salt and Fire (2016), i którym niespodziewanie - ale jednak może dość ironicznie - hołdował w Królowej pustyni. To, że stanowią one w dorobku reżysera swego typu obcą tkankę, zostało w prześmiewczy sposób ukazane w filmie Zaka Penna Incydent w Loch Ness (Incident at Loch Ness, 2004) — mockumencie opowiadającym o Herzogu próbującym nakręcić dokument o zagadce słynnego potwora i napotykającym rozmaite przeszkody, z których największe piętrzy producent (grany przez samego Penna), starający się na siłę skomercjalizować realizację, poprzez dodanie do niej typowo hollywoodzkich klisz w postaci atrakcyjnej aktorki, efektów specjalnych, takich

\footnotetext{
22 Ibidem, s. 205.

23 Ibidem, s. 172.

24 Ibidem, s. 203.

25 Ibidem, s. 202.
} 
jak makieta bestii z Loch Ness, i komediowych przerywników. Czyżby w tym projekcie pobrzmiewały echa negatywnych doświadczeń Herzoga związanych z poprawianiem jego scenariuszy przez hollywoodzkich decydentów?

Trudno jednoznacznie odpowiedzieć na to pytanie. Ważniejsze wydaje się to, że Incydent $w$ Loch Ness w pewien sposób ujmuje szczególny status Wernera Herzoga w Hollywood: wszak Zak Penn, który reżyseruje filmy stosunkowo rzadko, jest współscenarzystą głośnych hollywoodzkich blockbusterów, między innymi z serii X-Men i Avengers. Realizując mockument o Herzogu ścigającym Nessie, twórca pokazuje portret reżysera, który przyjmuje w swoim domu na kolacji Jeffa Goldbluma, a potem jedzie do Europy, by za stosunkowo małe pieniądze nakręcić kolejny film dokumentalny. Taki obraz Herzoga wydaje się na swój sposób trafny. Reżyser Stroszka osiągnął przecież taki status, że nie musi zabiegać o wsparcie wielkich wytwórni, by skompletować na planie gwiazdorską obsadę, o czym świadczy udział Tima Rotha w Niezwyciężonym (Invincible, 2001), Christiana Bale'a w Operacji Świt, Nicholasa Cage'a w Złym poruczniku oraz Nicole Kidman, Roberta Pattinsona i Jamesa Franco w Królowej pustyni. Z całą pewnością nie musi także stawać się drugim Fritzem Langiem: realia współczesnego amerykańskiego kina umożliwiają mu zajęcie dość wygodnej pozycji między mainstreamem, z którego przedstawicielami czasem współpracuje, a kinem niezależnym, do którego nominalnie przypisywane są jego ostatnie filmy fabularne.

Realia te są w dużej mierze efektem wytworzenia się w latach dziewięćdziesiątych XX wieku swoistej sfery pośredniej pomiędzy wysokobudżetowym kinem hollywoodzkim a coraz bardziej zyskującym na prestiżu i popularności sektorem niskobudżetowych realizacji. Tak zwany Indiewood (połączenie independent cinema i Hollywood) bywa ambiwalentnie postrzegany: $\mathrm{z}$ jednej strony jako przestrzeń owocnej współpracy komercyjnych wytwórni z twórcami o wysokim artystycznym potencjale, $\mathrm{z}$ drugiej zaś jako strefa niebezpiecznego kompromisu, w której dziedzictwo kina niezależnego zostaje zaprzedane wielkiemu i bezdusznemu systemowi. Zainicjowane sukcesami wytwórni Miramax, która wypromowała takie realizacje, jak Seks, ktamstwa i kasety wideo (Sex, Lies, and Videotape, 1989) Stevena Soderbergha, Gra pozorów (The Crying Game, 1992) Neila Jordana oraz Pulp Fiction (1994) Quentina Tarantino, istnienie Indiewood nie tylko umożliwiło osiągnięcie spektakularnych sukcesów początkującym niezależnym twórcom pokroju Darrena Aronofsky'ego i Christophera Nolana, lecz także przyczyniło się do wypracowania nowych jakości estetycznych oraz oryginalnych strategii marketingowo-dystrybucyjnych ${ }^{26}$.

Spośród wszystkich chwytów, jakimi Indiewood posługuje się w celu przyciągnięcia szerokiej publiczności oraz uwagi krytyki, trzy wydają się najistotniejsze: próba dodania artystycznego prestiżu mainstreamowym konwencjom, przy-

26 Więcej na ten temat: G. King, Indiewood, USA. Where Hollywood meets independent cinema, London-New York 2009, s. 94. 
bliżanie niezależnych projektów szerszej publiczności oraz włączanie w obręb mainstreamu jakości bliskich kinu kultowemu (mainstreaming the cult). Herzog, który na stałe związał się ze Stanami Zjednoczonymi w czasach, gdy Indiewood święcił największe triumfy, wpisuje się, co ciekawe, zarówno w pierwszą (swoimi filmami fabularnymi), jak i w drugą (filmami dokumentalnymi) ze wspomnianych strategii. Realizacja Niezwyciężonego, Operacji Świt, Złego porucznika czy Królowej pustyni stanowiła wszak w pewnej mierze typowy dla Indiewood wynik łączenia komercyjnych tematów i gatunkowych formuł z artystycznym prestiżem, jakiego dodawała im towarzysząca reżyserowi aura twórcy genialnych, ale trudnych w odbiorze, kontemplacyjnych filmów. Z kolei festiwalowe sukcesy najgłośniejszych i zdobywających prestiżowe nagrody dokumentów Herzoga Spotkan na krańcach świata (Encounters at the End of the World, 2007) oraz Jaskini zapomnianych snów (Cave of Forgotten Dreams, 2010) — przyczyniły się do ich szerszej międzynarodowej dystrybucji. Warto w tym miejscu zauważyć, że w ostatnich latach Werner Herzog zdecydowanie częściej podejmuje się realizacji filmów dokumentalnych niż fabularnych. Powodów takiego stanu rzeczy można znaleźć wiele ${ }^{27}$, najistotniejszy wśród nich wydaje się jednak fakt, że w realiach kina amerykańskiego twórca jest $\mathrm{w}$ stanie zachować znacznie większą kontrolę nad filmem dokumentalnym niż nad filmem fabularnym. Innymi słowy, dokumentalizm wydaje się bardziej odpowiadać temperamentowi reżysera, skłonnego do eksperymentowania z możliwościami medium, przywiązanego do swojej artystycznej wizji i lepiej znoszącego trudy pracy z niewielką ekipą, poza presją wielkich studiów ${ }^{28}$.

\section{$* * *$}

Jak dowodzi Dan North ${ }^{29}$, niezrealizowany film może pełnić rozmaite funkcje. Czasem pozwala dopełnić wizerunek wielkiej gwiazdy, tak jak fragmenty nieukończonego z powodu śmierci Marilyn Monroe Something's Got to Give (1962), ujęte po latach w format telewizyjnego filmu Marilyn Monroe: Ostatnie dni (Marilyn Monroe: The Final Days, reż. P. Ivins Specht, 2001). Innym razem projekty tego typu stają się przyczynkiem do odsłonięcia ekonomicznych, społecznych i kulturowych uwikłań filmowego przemysłu, a nawet - jak w wypadku Orsona Wellesa - pomagają zbudować legendę wybranego twórcy jako

27 Jeszcze w latach osiemdziesiątych tendencję reżysera do zajmowania się równolegle projektami fabularnymi i dokumentalnymi dość szczegółowo analizował William Van Wert, Last Words. Observations on a New Language, [w:] The Films of Werner Herzog. Between Mirage and History, red. T. Corrigan, London-New York 2014, s. 51-53.

28 Zob. ibidem, s. 52.

29 Zob. D. North, Introduction Finishing the Unfinished, [w:] Sights Unseen. Unfinished British Films, red. D. North, Newcastle 2008, s. 2-5. 
niepokornego artysty, geniusza niezrozumianego przez krótkowzrocznych i nakierowanych na komercyjny sukces producentów. Przypadek The Conquest of Mexico zdaje się łączyć oba te aspekty: $\mathrm{z}$ jednej strony uzupełnia wizerunek Wernera Herzoga o wysoce pożądany w wypadku ikony kina autorskiego element polemiki z kinem głównego nurtu, z drugiej zaś ujawnia mechanizmy sterujące przeobrażeniami amerykańskiej kinematografii od lat osiemdziesiątych do późnych dziewięćdziesiątych.

Przyczyny porażki projektu są dość oczywiste: w czasach, kiedy istniały szanse na sukces filmu, czyli na początku lat osiemdziesiątych, zabrakło środków na jego realizację, z kolei kiedy środki się znalazły, producenci zaczęli zbyt mocno ciążyć ku idei blockbustera, obcej Herzogowi, który postanowił bronić swojej artystycznej wizji za cenę możliwości nakręcenia dzieła. Na pytanie o przyczyny fiaska długofalowego projektu, w jaki realizacja o konkwiście była uwikłana, czyli prób podjęcia bliskiej współpracy z Hollywood, trudniej jest znaleźć odpowiedź. Z pewnością po obu stronach zabrakło determinacji: ani Hollywood nie postrzegał Herzoga jako reżysera o komercyjnym potencjalne, ani Herzog nie widział w Hollywood bezwzględnie właściwego kierunku rozwoju swojej kariery. Porównanie z Fritzem Langiem, bardzo pochlebne dla twórcy Stroszka, nie bierze pod uwagę faktu, iż w czasach, gdy autor Metropolis (1926) emigrował do Ameryki, możliwości realizowania się w kinie poza systemem wielkich wytwórni były nikłe; Herzog nigdy nie odczuwał tak wielkiej presji dostosowania się do wymogów mainstreamu: jako ikona europejskiego kina autorskiego, twórca identyfikowany z niezależnymi projektami oraz z głośnymi filmami dokumentalnymi, mógł znaleźć dla siebie bezpieczną niszę w obszarze Indiewood i potraktować plan współpracy z Hollywood po prostu jako jedną z dostępnych opcji, kolejny środek do uzbierania owej małej sterty pieniędzy niezbędnej do realizacji swoich pomysłów. A to już całkiem wiele dla autora, dla którego kino to sposób na życie. Nawet jeżeli Meksyk ostatecznie okazał się iluzją, to przecież całe kino Herzoga opowiada o wizjach, marzeniach, snach i niezrealizowanych ideach. I podobnie jak Fitzcarraldo, który nie zbudował opery w środku dżungli, ale nie wrócił z niej całkiem pokonany, reżyser Stroszka nie poległ w starciu z dżunglą Hollywood, wynosząc z niej cenne doświadczenia.

\section{Unfinished conquest. \\ On Werner Herzog's unmade film project}

Abstract

The paper shows Werner Herzog's unmade project The Conquest of Mexico in the context of the director's complex relations with mainstream cinema. The film which was supposed to initiate closer Werner Herzog-Francis Ford Coppola cooperation with time became known as one of cin- 
ema's "unfinished masterpieces". Trying to pinpoint the causes of the project's failure, the author of the paper analyses the status of European auteur in contemporary Hollywood. One of the main contexts of the analysis is Indiewood, where the influence of mainstream cinema meets the potential of independent cinema and where such directors as Werner Herzog may find their place without the necessity of abandoning their artistic visions.

Keywords: The Conquest of Mexico, Werner Herzog in America, Indiewood

\section{Bibliografia}

Adamczak M., Jak istnieje film? O ruchomych obiektach i teorii Aktora-Sieci Bruno Latoura, [w:] Kino, którego nie ma, red. P. Zwierzchowski, D. Wierski, Bydgoszcz 2013.

Chute D., Coppola's rainbow, http://articles.latimes.com/1998/aug/14/entertainment/ca-12942/ (dostęp: 20 sierpnia 2018).

Cronin P., Herzog on Herzog, London-New York 2002.

Demby Ł., O wrażeniu nieistnienia kina. Koncepcja kina mentalnego na przykładzie wybranych watków z teorii kina, [w:] Kino, którego nie ma, red. P. Zwierzchowski, D. Wierski, Bydgoszcz 2013.

Ebiri B., Werner Herzog on death, Los Angeles and avoiding introspection, http://www.ifc.com/ 2010/09/werner-herzog-my-son (dostęp: 30 sierpnia 2018).

Giżycki M., Wenders do domu! Europejskie filmy o Ameryce i ich recepcja w Stanach Zjednoczonych, Gdańsk 2006.

Gonzalez U., Werner Herzog loves LA: It's 'the city with the most substance', http://www.thewrap. com/werner-herzog-says-los-angeles-city-most-substance/ (dostęp: 30 sierpnia 2018).

King G., Indiewood, USA. Where Hollywood meets independent cinema, London-New York 2009.

McCarthy E., 14 Things we learned from Werner Herzog's Reddit AMA, http://mentalfloss.com/article/83030/14-things-we-learned-werner-herzogs-reddit-ama (dostęp: 30 sierpnia 2018).

North D., Introduction. Finishing the Unfinished, [w:] Sights Unseen. Unfinished British Films, red. D. North, Newcastle 2008.

O'Brien G., Geoffrey O'Brien with Werner Herzog, http://parnassusreview.com/archives/388 (dostęp: 30 sierpnia 2018).

Sragow M., Francis Ford Coppola, http://www.salon.com/1999/10/19/coppola/ (dostęp: 30 sierpnia 2018).

Unmade masterpieces: Werner Herzog's The Conquest of Mexico, https://www.youtube.com/watch? $\mathrm{v}=\mathrm{u} 5$ SnJ9tKeWE (dostęp: 30 sierpnia 2018).

Van Wert W., Last Words. Observations on a New Language, [w:] The Films of Werner Herzog. Between Mirage and History, red. T. Corrigan, London-New York 2014.

Zigman C., Werner Herzog's Hollywood, http://www.hollywoodfiveo.com/archive/issue2/cinema/herzog.htm (dostęp: 30 sierpnia 2018).

\section{Źródła internetowe}

http://thisisinsider.com/the-best-movies-never-made-2016-9\#the-conquest-of-mexico-by-wernerherzog-5 (dostęp: 20 sierpnia 2018).

http://www.cinelinx.com/editorial/item/3282-classics-that-might-have-been-25-unmade-filmspart-1.html (dostęp: 20 sierpnia 2018). 
http://www.faena.com/aleph/articles/the-films-and-books-werner-herzogs-students-must-watchand-read/ (dostęp: 30 sierpnia 2018).

http://www.tasteofcinema.com/2014/the-25-greatest-films-you-may-never-get-to-see/3/ (dostęp: 20 sierpnia 2018).

https://www.filmcomment.com/article/unproduced-and-unfinished-films-a-ongoing-film-commentproject/ (dostęp: 20 sierpnia 2018). 